Andrzej Zatęskil, ${ }^{l, 2}$ Martyna Szwejkowska³, Dominika Rykowska ${ }^{3}$, Aneta Nitsch-Osuch ${ }^{4}$

\title{
IMPACT OF PARENTAL TOBACCO SMOKING ON INFLUENZA AND OTHERS RESPIRATORY INFECTIONS MORBIDITY IN CHILDREN
}

\author{
WPŁYW PALENIA TYTONIU PRZEZ RODZICÓW NA ZACHOROWANIA DZIECI \\ NA GRYPĘ I INNE INFEKCJE UKŁADU ODDECHOWEGO
}

\author{
${ }^{1}$ Medical University of Warsaw, Department of Infectious Diseases, Tropical Diseases and Hepatology \\ ${ }^{2}$ Hospital for Infectious Diseases, Warsaw, Poland \\ ${ }^{3}$ Medical University of Warsaw, Department of Paediatrics with Clinical Decision Unit \\ ${ }^{4}$ Medical University of Warsaw, Department of Social Medicine and Public Health \\ ${ }^{1}$ Warszawski Uniwersytet Medyczny, Klinika Chorób Zakaźnych, Tropikalnych i Hepatologii \\ ${ }^{2}$ Wojewódzki Szpital Zakaźny w Warszawie \\ ${ }^{3}$ Warszawski Uniwersytet Medyczny, Oddział Kliniczny Obserwacyjno-Izolacyjny i Pediatrii \\ ${ }^{4}$ Warszawski Uniwersytet Medyczny, Katedra Medycyny Społecznej i Zdrowia Publicznego
}

\section{ABSTRACT}

BACKGROUND. The predisposition of cigarette smokers for the development of respiratory infections, including influenza, have been well documented. As well, those exposed to side stream smoke are prone to viral and bacterial infections of the respiratory tract.

AIM. The study aimed to evaluate whether the prevalence of smoking parents is higher among children with respiratory tract infections, including influenza, in comparison to the general population.

MATERIAL AND METHODS. Observational, cohort study. The authors surveyed a cohort of patients and their families, hospitalized in the Paediatric University Hospital in Warsaw during 2018 influenza season. Patients were diagnosed with influenza (using PCR) or other respiratory tract infections. A questionnaire on smoking habits was performed.

RESULTS. Overall, 72 patients were included in the study, median age 2 years and 9 months (IQR: $1.4-7.2$ ), influenza was diagnosed in $43 \%(\mathrm{n}=31)$ of patients. The percentage of regularly smoking parents in the whole cohort amounted to $33.3 \%$ (44 of 132) and was statistically significantly higher $(p<0.05)$ than in the general population $(22.7 \%)$, whereas in the subgroup with influenza and non-influenza infections it reached $32.2 \%$ and $34.2 \%$, respectively.

CONCLUSIONS. The prevalence of smoking parents of children with acute respiratory tract infections is higher than in the general population: exposing children to tobacco smoke is one of the risk factors for acquiring influenza and others respiratory tract infections. Quitting smoking can decrease the risk of infectious diseases.

Key words: influenza, infections, children, tobacco, side stream smoking

\section{STRESZCZENIE}

WSTĘP. Predyspozycje palaczy papierosów do rozwoju infekcji dróg oddechowych, w tym grypy, zostały dobrze udokumentowane. Podobnie, osoby narażone na bierne palenie częściej nabywają zarówno wirusowe jak i bakteryjne schorzenia dróg oddechowych.

CEL PRACY. Badanie miało na celu ocenę, czy palenie wśród rodziców dzieci z infekcjami dróg oddechowych, w tym z grypą, jest częstsze w porównaniu z populacją ogólną.

MATERIAŁ I METODY. Badanie obserwacyjne, kohortowe. Autorzy przeprowadzili ankietę wśród rodziców pacjentów hospitalizowanych w Szpitalu Pediatrycznym Uniwersytetu Medycznego w Warszawie w trakcie 
sezonu grypowego w 2018 roku. U pacjentów zdiagnozowano grypę (za pomocą metody PCR) lub inne infekcje dróg oddechowych. Przeprowadzono kwestionariusz dotyczący nawyków palenia.

WYNIKI. Do badania zakwalifikowano 72 pacjentów, z medianą wieku 2 lata i 9 miesięcy (IQR: 1,4 - 7,2), grypę rozpoznano u $43 \%(\mathrm{n}=31)$ pacjentów. Odsetek rodziców regularnie palących w całej kohorcie wyniósł $33,3 \%$ (44 z 132) i był statystycznie istotnie wyższy $(\mathrm{p}<0,05)$ niż w populacji ogólnej $(22,7 \%)$, podczas gdy $\mathrm{w}$ podgrupach z zakażeniami grypą i innymi infekcjami dróg oddechowych wynosił odpowiednio $32,2 \%$ i $34,2 \%$.

WNIOSKI. Odsetek palących rodziców dzieci z ostrymi zakażeniami dróg oddechowych jest wyższy niż odsetek palących osób w populacji ogólnej: narażenie dzieci na dym tytoniowy jest jednym z czynników ryzyka zachorowania na grypę i inne infekcje dróg oddechowych. Ograniczenie ekspozycji na dym tytoniowy może zmniejszyć ryzyko nabycia chorób zakaźnych.

Słowa kluczowe: grypa, infekcje, dzieci, dym tytoniowy, bierne palenie

\section{INTRODUCTION}

Chronic exposure of the airways to smoke-derived toxicants is the primary cause of the progressive pulmonary disease and lung cancer. As well, the predispositions of cigarette smokers for the development of respiratory infections, including influenza are well recognized (1-5). The risk of infections also increases in those inadvertently exposed to side stream smoke, with the overall risk being approximately double that in non-exposed (4).

Environmental tobacco smoke(ETS) can predispose to respiratory infections in children, because smokederived toxicants have a suppressive effect on the functions of immune and respiratory systems. ETS has also a direct effect on microbial pathogens, as it facilitates microbial virulence and promotes drug resistance $(1,5-7)$.

Adverse health consequences of exposing children to ETS, including increase in incidence of respiratory tract infections, have been showed in many health reports (4). Those exposed to side stream smoke are prone to viral infections of the upper respiratory tract, caused among others by rhinoviruses, and lower respiratory tract infections, caused by influenza as well as pneumonia and invasive diseases caused by various bacterial pathogens $(1,8-12)$.

The percentage of smokers, both addicts and occasional smokers, was estimated in Poland in 2014 at $26 \%, 22.7 \%$ of people smoked regularly (13). Despite a substantial decrease in the share of chain-smokers, their proportion in the Polish population is still higher than in the European Union (1.7 percentage point in 2014). Moreover, about a quarter of the Polish smokers declare that they smoke in the presence of children or pregnant women $(9,13)$.

\section{WSTĘP}

Narażenie dróg oddechowych na toksyczne składniki dymu jest główną przyczyną przewlekłej obturacyjnej choroby płuc, a także raka płuc. Również predyspozycje palaczy papierosów do rozwoju infekcji dróg oddechowych, w tym grypy, zostały dobrze udokumentowane (1-5). Ryzyko infekcji wzrasta także u biernych palaczy: jest około dwukrotnie większe niż u osób nieeksponowanych na dym tytoniowy (4).

Ekspozycja na dym tytoniowy (ang. environmental tobacco smoke, ETS) może uwrażliwiać dzieci na infekcje dróg oddechowych, ponieważ toksyczne składniki dymu działają niekorzystnie na funkcje układu immunologicznego i oddechowego. ETS ma również bezpośredni wpływ na patogeny chorobotwórcze: zwiększa zjadliwość drobnoustrojów i ułatwia nabywanie lekooporności (1,5-7).

Niekorzystne konsekwencje zdrowotne narażenia dzieci na ETS, w tym wzrost częstości infekcji układu oddechowego są przedstawione $\mathrm{w}$ wielu obszernych raportach zdrowotnych (4). Bierni palacze są podatni na infekcje wirusowe górnych dróg oddechowych spowodowane między innymi przez rinowirusy i dolnych dróg oddechowych spowodowane przez grypę, a także na zapalenia płuc oraz choroby inwazyjne wywołane przez różne patogeny bakteryjne $(1,8-12)$.

Odsetek palaczy wśród osób powyżej 14 roku życia, zarówno palących codziennie jak i okazjonalnie, oszacowano w Polsce w 2014 r. na 26\%, 22,7\% osób paliło regularnie (13). Mimo znacznego spadku liczby osób palących w polskiej populacji, odsetek ten jest nadal wyższy niż w pozostałych krajach Unii Europejskiej (o około 1,7 punktu procentowego w 2014 r.). Ponadto około jedna czwarta polskich palaczy deklaruje, że pali w obecności dzieci lub kobiet w ciąży $(9,13)$. 


\section{AIM OF STUDY}

The study was designed to assess the incidence of exposure to tobacco smoke among children with laboratory-confirmed influenza and other respiratory infections.

\section{MATERIAL AND METHODS}

\section{Study design}

An observational cohort study was performed on a cohort of patients, hospitalized in the Paediatric Teaching Hospital of the Medical University of Warsaw, in the peak of influenza season-between February and April 2018. The authors had obtained an approval of the Warsaw Medical University Research Ethics Committee (consent number: KB/85/2016).

\section{Inclusion criteria included:}

1. influenza-like illness (ILI) symptoms during past 48 hours but not longer than one week,

2. age less than 18 years,

3. signed consent of legal guardians for taking part in the study.

Influenza-like illness (ILI) was diagnosed if at least one of the following general symptoms occurred: headache, fever, myalgia or malaise, and at least one of the following respiratory symptoms were present: cough, shortness of breath or sore throat.

Exclusion criteria included: hospitalization in the previous 30 days, long-term facilities care and lack of the consent of legal guardians for participating in the study.

\section{Procedure}

The nasopharyngeal swabs were obtained from all patients enrolled to the study. Before sending samples to a reference laboratory, swabs were kept in -20 Celsius degree for maximum 72 hours. Real-Time PCR was used for influenza A (H1N1 and H3N2) and influenza $\mathrm{B}$ detection. The sensitivity and specificity of PCR were $94,8-100 \%$ and $100 \%$, respectively (14). Protocols for RT-PCR detection and subtyping of influenza complied with the latest WHO guidelines (15). Following tools were used for testing:

1. nylon flocked dry swabs in peel pouch and medium without swabs (Cat no: 516CS01 and Cat no: 350C, Copan, Italy),

2. multiplex RT-PCR-Xpert ${ }^{\circledR}$ Flu for influenza A (AH1N1, AH3N2) and influenza B lineage detection.

\section{CEL PRACY}

Badanie miało na celu ocenę częstości występowania narażenia na dym tytoniowy wśród dzieci z potwierdzoną laboratoryjnie grypą lub z innymi infekcjami dróg oddechowych.

\section{MATERIAŁ I METODY}

\section{Projekt badania}

Badanie obserwacyjne kohortowe przeprowadzono na grupie pacjentów hospitalizowanych w Dziecięcym Szpitalu Klinicznym Warszawskiego Uniwersytetu Medycznego, w szczycie sezonu grypowego - od lutego do kwietnia 2018 r. Autorzy uzyskali zgodę Komisji Bioetycznej Warszawskiego Uniwersytetu Medycznego (numer zgody: KB/85/2016).

\section{Kryteria włączenia obejmowały:}

1. objawy choroby grypopodobnej (ang. influenza-like disease, ILI) w ciągu ostatnich 48 godzin, ale nie dłużej niż tydzień,

2. wiek poniżej 18 lat,

3. podpisana zgoda opiekunów prawnych na udział w badaniu.

Chorobę grypopodobną (ILI) zdiagnozowano, jeśli wystąpił co najmniej jeden z następujących objawów ogólnych: ból głowy, gorączka, bóle mięśni lub złe samopoczucie oraz co najmniej jeden z następujących objawów ze strony układu oddechowego: kaszel, duszność lub ból gardła.

Kryteria wykluczenia obejmowaly: hospitalizację w ciągu ostatnich 30 dni, długoterminową opiekę w placówkach opieki oraz brak zgody opiekunów prawnych na udział w badaniu.

\section{Procedura}

Wymazy z jamy nosowo-gardłowej uzyskano od wszystkich pacjentów włączonych do badania. Przed wysłaniem próbek do laboratorium referencyjnego wymazy przechowywano w temperaturze minus 20 stopni Celsjusza przez maksymalnie 72 godziny. PCR w czasie rzeczywistym zastosowano do wykrywania wirusów grypy A (H1N1 i H3N2) i grypy B. Czułość i swoistość RT-PCR wyniosły odpowiednio: 94,8-100\% i 100\% (14). Protokoły wykrywania metodą RT-PCR i określania podtypu grypy były zgodne z najnowszymi wytycznymi WHO (15). Do testowania wykorzystano następujące narzędzia:

1. suche, nylonowe waciki w opakowaniu oraz podłoże bez wymazówki (nr kat.: 516CS01 i nr kat.: 350C, Copan, Włochy),

2. multiplex RT-PCR - Xpert ${ }^{\circledR}$ Flu do wykrywania grypy A (AH1N1, AH3N2) i grypy B. 


\section{Data collection}

An interview with legal guardians was performed and a questionnaire form concerning smoking habits was completed. The information on whatever parents were present or never smokers was included in the questionnaire. Parents who smoke tobacco at least 1 cigarette per day, every day, were considered as a regularly smoking parents. Furthermore, the questionnaire form included influenza vaccination status for the three last years and the history of chronic diseases.

\section{Statistical methods}

The distribution of continuous variables was analysed with the Shapiro-Wilk test. Median and interquartile range (IQR) were established based on the test data. Quantitative data were analysed between groups, using the U Mann-Whitney test, and qualitative data were compared using $\chi^{2}$ test or Fisher exact test. $\mathrm{P}$ value $<0.05$ was considered statistically significant.

The authors have compared the data on the prevalence of smoking parents of children with respiratory tract infections in comparison to the general population in Poland. In addition, an analysis was conducted in the subgroups of children with laboratory-confirmed influenza $(\mathrm{LCI}+)$ and children with non-influenza respiratory tract infections (LCI-).

\section{RESULTS}

On the basis of inclusion and exclusion criteria 72 patients (61\% males) were recruited, with median age 2 years and 9 months (IQR 1,4-7,2), 64 of patients were younger than 5 years. Characteristic of the cohort is presented in table 1 .

Table I. Characteristic of the cohort

\begin{tabular}{|c|c|c|c|c|}
\hline $\begin{array}{c}\text { Number - n. } \\
(\%)\end{array}$ & LC- & $\mathrm{LC}+$ & \begin{tabular}{|c|} 
Influenza \\
A
\end{tabular} & \begin{tabular}{|c|} 
Influenza \\
B
\end{tabular} \\
\hline $\begin{array}{l}\text { Male } \\
\text { gender }\end{array}$ & $23(52 \%)$ & $21(48 \%)$ & $\begin{array}{c}9 \\
(20.5 \%)\end{array}$ & $\begin{array}{c}12 \\
(27.5 \%)\end{array}$ \\
\hline $\begin{array}{l}\text { Female } \\
\text { gender }\end{array}$ & $18(64 \%)$ & $10(36 \%)$ & $3(11 \%)$ & $7(25 \%)$ \\
\hline 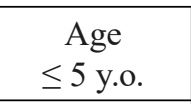 & $30(65 \%)$ & $16(35 \%)$ & $9(20 \%)$ & $7(15 \%)$ \\
\hline $\begin{array}{c}\text { Age } \\
>5 \text { y.o. }\end{array}$ & $11(42 \%)$ & $15(58 \%)$ & $9(35 \%)$ & $6(23 \%)$ \\
\hline $\begin{array}{c}\text { Any } \\
\text { chronic } \\
\text { disease }\end{array}$ & $11(55 \%)$ & $9(45 \%)$ & $7(35 \%)$ & $2(10 \%)$ \\
\hline $\begin{array}{l}\text { No chronic } \\
\text { disease }\end{array}$ & $30(58 \%)$ & $22(42 \%)$ & $11(21 \%)$ & $11(21 \%)$ \\
\hline
\end{tabular}

\section{Zbieranie danych}

Przeprowadzono wywiad z opiekunami prawnymi oraz wypełniono kwestionariusz dotyczący nawyków palenia. Informacje na temat rodzaju nałogu (osoby aktualnie palące, osoby nigdy nie palące), zostały uwzględnione w kwestionariuszu. Rodziców palących przynajmniej 1 papierosa na dobę, codziennie, uznano za rodziców palących regularnie. Ponadto dane z kwestionariusza obejmowały wywiad dotyczący szczepień przeciwko grypie w ciągu ostatnich trzech lat oraz wywiad dotyczący chorób przewlekłych.

\section{Metody statystyczne}

Rozkład zmiennych ciągłych analizowano za pomocą testu Shapiro-Wilka. Na podstawie danych obliczono medianę i zakres międzykwartylowy (IQR) zmiennych. Dane ilościowe analizowano między grupami, stosując test U Manna-Whitneya, a dane jakościowe porównywano za pomocą testu $\chi^{2}$ lub testu Fishera. Wartość p $<0,05$ uznano za statystycznie istotną.

Autorzy porównali dane dotyczące częstości palenia wśród rodziców dzieci z infekcjami dróg oddechowych w porównaniu z populacją ogólną w Polsce. Ponadto przeprowadzono analizę $\mathrm{w}$ podgrupach dzieci z potwierdzoną laboratoryjnie grypą (ang. laboratoryconfirmed influenza, LCI +) i dzieci z nie grypowymi zakażeniami dróg oddechowych (LCI-).

\section{WYNIKI}

Na podstawie kryteriów włączenia i wyłączenia zrekrutowano 72 pacjentów (61\% płci męskiej), z medianą wieku wynoszącą 2 lata i 9 miesięcy (IQR 1,4 - 7,2), 64 pacjentów było w wieku poniżej 5 lat. Charakterystykę kohorty przedstawiono w tabeli 1 .

Tabela I. Charakterystyka kohorty

\begin{tabular}{|c|c|c|c|c|}
\hline $\begin{array}{c}\text { Liczba }-n, \\
(\%)\end{array}$ & LC- & $\mathrm{LC}+$ & Grypa A & Grypa B \\
\hline Płeć męska & $23(52 \%)$ & $21(48 \%)$ & $\begin{array}{c}9 \\
(20,5 \%) \\
\end{array}$ & $\begin{array}{c}12 \\
(27,5 \%) \\
\end{array}$ \\
\hline Płeć żeńska & $18(64 \%)$ & $10(36 \%)$ & $3(11 \%)$ & $7(25 \%)$ \\
\hline $\begin{array}{r}\text { Wiek } \\
\leq 5 \text { lat. }\end{array}$ & $30(65 \%)$ & $16(35 \%)$ & $9(20 \%)$ & $7(15 \%)$ \\
\hline $\begin{array}{c}\text { Wiek } \\
>5 \text { lat. }\end{array}$ & $11(42 \%)$ & $15(58 \%)$ & $9(35 \%)$ & $6(23 \%)$ \\
\hline $\begin{array}{c}\text { Choroby } \\
\text { przewlekłe }\end{array}$ & $11(55 \%)$ & $9(45 \%)$ & $7(35 \%)$ & $2(10 \%)$ \\
\hline $\begin{array}{c}\text { Brak } \\
\text { choroby } \\
\text { przewlekłej }\end{array}$ & $30(58 \%)$ & $22(42 \%)$ & $11(21 \%)$ & $11(21 \%)$ \\
\hline
\end{tabular}


One third of the patients (28\%) suffered from a chronic disease, with the most frequent diseases being: asthma, neuromuscular and cardiovascular diseases. Two patients had more than one chronic condition. (Tab.I and II). One patient with neuromuscular disease (cerebral palsy) died of pneumonia caused by influenza, and one patient with asthma required treatment in the Intensive Care Unit (ICU).

Table II. Chronic conditions in cohort

\begin{tabular}{|c|c|c|}
\hline Chronic disease & number & $\begin{array}{c}\% \text { with } \\
\text { influenza } \\
(\mathrm{LC}+)\end{array}$ \\
\hline asthma & 7 & $57 \%$ \\
\hline cardiovascular disease & 6 & $33 \%$ \\
\hline neuromuscular disease & 5 & $60 \%$ \\
\hline immunodeficiency & 3 & $33 \%$ \\
\hline liver disease & 1 & $100 \%$ \\
\hline renal impairment & 1 & $0 \%$ \\
\hline
\end{tabular}

Laboratory-confirmed influenza ( $\mathrm{LCI}+)$ was diagnosed in $43 \%(\mathrm{n}=31)$, whereas non-influenza infection (PCR for influenza negative) of the respiratory tract (LCI - negative) was recognized in 57 $\%$ of the cohort. Virus distribution by age and gender is presented in table $1.61 \%$ of patients with confirmed influenza were diagnosed with type B (80\% Yamagata line), while $39 \%$ with type A (67\% - AH1N1pdm2009).

In the study, the percentage of regularly smoking parents (number of regularly smoking parents in whole cohort of parents) of children with all respiratory tract infections amounted to $33.3 \%$ (44 out of 132) and it was statistically significantly higher $(\mathrm{p}<0.05)$ than in the general population (22.7\%). An analysis in the subgroups of LCI+ and LCI- patients revealed the
Jedna trzecia pacjentów (28\%) chorowała przewlekle, najczęściej na: astmę, choroby nerwowo-mięśniowe oraz choroby układu krążenia. Dwójka pacjentów miała więcej niż jedną chorobę przewlekłą (Tab. I, II). Jeden z pacjentów z chorobą nerwowo-mięśniową (mózgowe porażenie dziecięce) zmarł $\mathrm{z}$ powodu zapalenia płuc spowodowanego zakażeniem wirusem grypy, a jeden pacjent $\mathrm{z}$ astmą wymagał leczenia na Oddziale Intensywnej Terapii (OIT).

Table II. Choroby przewlekłe w badanej kohorcie

\begin{tabular}{|l|c|c|}
\hline \multicolumn{1}{|c|}{ Choroba przewlekła } & liczba & $\begin{array}{c}\% \text { z grypą } \\
\text { (LC+) }\end{array}$ \\
\hline astma & 7 & $57 \%$ \\
\hline choroba układu krążenia & 6 & $33 \%$ \\
\hline $\begin{array}{l}\text { choroba nerwowo- } \\
\text { mięśniowa }\end{array}$ & 5 & $60 \%$ \\
\hline niedobór odporności & 3 & $33 \%$ \\
\hline choroba wątroby & 1 & $100 \%$ \\
\hline niewydolność nerek & 1 & $0 \%$ \\
\hline
\end{tabular}

Laboratoryjnie potwierdzoną grypę $(\mathrm{LCI}+)$ zdiagnozowano u $43 \%(n=31)$, podczas gdy zakażenie dróg oddechowych bez potwierdzonej grypy (badanie PCR dla grypy z wynikiem ujemnym, LCI -) rozpoznano u 57\% pacjentów. Dystrybucję wirusa według wieku i płci przedstawiono w tabeli 1 . U $61 \%$ pacjentów z potwierdzoną grypą zdiagnozowano typ B $(80 \%$ linii Yamagata), podczas gdy u 39\% typ A (67\% AH1N1pdm2009).

W badaniu częstość palenia tytoniu wśród rodziców (liczba rodziców palących regularnie w grupie wszystkich rodziców) dzieci z infekcjami dróg oddechowych wyniosła $33,3 \%$ (44 z 139) i była istotnie statystycznie wyższa $(p<0,05)$ niż w populacji ogól-

Table III. Smoking frequency in parents of children enrolled in the study

\begin{tabular}{|c|c|c|c|}
\hline & $\begin{array}{c}\text { Smoking frequency in } \\
\text { parents of the children from } \\
\text { the cohort }(\%) ;\end{array}$ & $\begin{array}{c}\text { Smoking frequency in } \\
\text { general population (\%) }\end{array}$ & Statistical significance (p) \\
\hline LC $(+)$ and LC $(-)$ & $44 / 132(33.3 \%)$ & & $\mathrm{p}<0.05$ \\
\hline LC $(+)$ & $19 / 59(32.2 \%)$ & \multirow{2}{*}{$22.7 \%$} & $\mathrm{p}<0.05$ \\
\hline LC $(-)$ & $25 / 73(34.2 \%)$ & & $\mathrm{p}<0.05$ \\
\cline { 1 - 1 } & $21 / 38(55 \%)$ & & $\mathrm{p}<0.05$ \\
\hline
\end{tabular}

Tabela III. Wyniki badania częstości palenia przez rodziców dzieci włączonych do badania

\begin{tabular}{|c|c|c|c|}
\hline & $\begin{array}{l}\text { Częstość palenia przez } \\
\text { rodziców w badanej } \\
\text { kohorcie }(\%)\end{array}$ & $\begin{array}{c}\text { Częstość palenia w populaci } \\
\text { ogólnej }(\%)\end{array}$ & Istotność statystyczna (p) \\
\hline $\mathrm{LC}(+)$ i LC (-) & $44 / 132(33,3 \%)$ & \multirow{4}{*}{$22,7 \%$} & $\mathrm{p}<0,05$ \\
\hline $\mathrm{LC}(+)$ & $19 / 59(32,2 \%)$ & & $\mathrm{p}<0,05$ \\
\hline LC (-) & $25 / 73(34,2 \%)$ & & $\mathrm{p}<0,05$ \\
\hline obecna choroba przewlekła & $21 / 38(55 \%)$ & & $\mathrm{p}<0,05$ \\
\hline
\end{tabular}


prevalence of exposition to side-stream smoke in the amount of $32.2 \%$ (19 out of 59) and 34.2\% (25 out of 73 ), respectively. Majority of parents - 55\% (21 out of 38) of children with chronic diseases were regular smokers. None of the patients received a vaccine against influenza during the current season nor the previous two seasons. Results are showed in table III.

\section{DISCUSSION}

Epidemiological results obtained in the study seem to be representative: data concerning influenza epidemiology in 2017/2018 season of the National Institute of Public Health-National Institute of Hygiene are congruent (16). There is a great probability that the high percentage of patients with laboratory confirmed influenza (43\%) who were enrolled to the study resulted not only from the inclusion criteria (symptoms of ILI), but also from the period of enrollment - the peak of 2018 influenza season in Poland. Secondly, the high percentage of patients with chronic diseases seem to result from extensive diagnostics in this group of patients, who are especially sensitive to the severe course of infectious diseases, as well as from the place of the enrollment of the patients - a tertiary university hospital, where the proportion of children patients with chronic diseases is greater than in other hospitals.

In the study, the prevalence of regularly smoking parents of children with acute respiratory tract infections is significantly higher than in the general population. The results correspond with data from other studies (1,9-12). According to the Polish epidemiological data, the percentage of regular smokers in the Polish population is estimated to range up to $22.7 \%$. Furthermore, about a quarter of the Polish smokers declare that they smoke in the presence of children (13). What is very concerning, the result of the study also show that the majority of the parents $(55 \%)$ of children with chronic diseases were smokers. There are also epidemiological data concerning on the number of polish smokers by gender, age and other demographic information (17). Unfortunately the study did not examine these differences, which can be considered as one of the disadvantages of the study.

In the Polish population, influenza vaccine coverage is very low: it estimated at a level 3.5\% each year, despite many educational campaigns (18). What is devastating, none of the enrolled patients, including those chronically ill, received a vaccine against influenza, which, along with the exposition to ETS, may result in excess morbidity. The increased number of infections can have significant long-term consequences, because children who suffer from respiratory tract infections in early life are at an nej (22,7\%). Analiza w podgrupach pacjentów z LCI+ oraz LCI- ujawniła występowanie biernego palenia w częstościach odpowiednio 32,2\% (19 z 59) i 34,2\% (25 z 73). Większość rodziców dzieci z chorobami przewlekłymi, bo az 55\% (21 z 38) to nałogowi palacze. Żaden z pacjentów nie otrzymał szczepionki przeciwko grypie zarówno w bieżącym sezonie ani w poprzednich dwóch sezonach. Wyniki przedstawiono w tabeli III.

\section{DYSKUSJA}

Wyniki epidemiologiczne uzyskane $\mathrm{w}$ badaniu wydają się być reprezentatywne: dane dotyczące epidemiologii grypy w sezonie 2017/2018 Narodowego Instytutu Zdrowia Publicznego-Państwowego Zakładu Higieny są zgodne (16). Istnieje duże prawdopodobieństwo, że wysoki odsetek pacjentów z potwierdzoną laboratoryjnie grypą (43\%), którzy wzięli udział w badaniu, wynikał nie tylko z kryteriów włączenia (objawy ILI), ale także z okresu rekrutacji - szczytu sezonu grypowego w 2018 r. w Polsce. Po drugie, wysoki odsetek pacjentów z chorobami przewlekłymi wydaje się wynikać nie tylko z szeroko prowadzonej diagnostyki wśród tych pacjentów, którzy są szczególnie wrażliwi na ciężki przebieg chorób zakaźnych, ale także z miejsca ich rekrutacji - referencyjnego szpitala uniwersyteckiego, w którym odsetek dzieci chorych na choroby przewlekłe jest większy niż w innych szpitalach.

W pracy częstość palenia tytoniu przez rodziców, których dzieci chorują na ostre zakażenia dróg oddechowych jest znacznie wyższa niż w populacji ogólnej. Wyniki te są zgodne $\mathrm{z}$ danymi z wielu innych badań $(1,9-12)$. Według danych epidemiologicznych w populacji polskiej odsetek osób palących regularnie sięga $22,7 \%$. Ponadto około jedna czwarta polskich palaczy deklaruje, że pali w obecności dzieci (13). Co bardzo niepokojące, wyniki badania pokazują, że większość rodziców (55\%) dzieci z chorobami przewlekłymi pali papierosy. Istnieją również dane epidemiologiczne dotyczące liczby polskich palaczy w zależności od płci, wieku i innych informacji demograficznych (17), Niestety nasza praca nie zbadała tych różnic, co można uznać za jedną z wad badania.

Odsetek osób zaszczepionych przeciwko grypie w populacji polskiej jest bardzo niski: szacuje się go na poziomie 3,5\% każdego roku, pomimo wielu kampanii edukacyjnych (18). Bardzo niepokojący jest fakt, że żaden $\mathrm{z}$ badanych pacjentów, $\mathrm{w}$ tym przewlekle chorych, nie otrzymał szczepionki przeciwko grypie, co wraz z ekspozycją na dym tytoniowy może prowadzić do wzrostu chorobowości. Zwiększona liczba infekcji może mieć długoterminowe konsekwencje, gdyż dzieci cierpiące na infekcje dróg oddechowych we wcze- 
increased risk of developing chronic diseases, such as asthma $(19,20)$.

Strategies preventing smoking that are addressed at parent and promoting preventing vaccinations can play a certain role in the reduction of morbidity resulting from the exposition to tobacco smoke in children $(7,21)$. New forms of interaction with patients need to be sought, and education is still of the highest importance.

\section{CONCLUSIONS}

Children with the influenza and other respiratory tract infections are more likely to be exposed to side stream smoke. Exposure to tobacco smoke may lead to an increased risk of developing respiratory infections, including influenza.

\section{REFERENCES}

1. Feldman C, Anderson R. Cigarette smoking and mechanisms of susceptibility to infections of the respiratory tract and other organ systems. J Infect. 2013; 67(3): 169-184.

2. Winnall WR, Bellew B, Greenhalgh EM, et al. 3.9 Increased susceptibility to infection in smokers. In Greenhalgh, EM, Scollo, MM and Winstanley, $\mathrm{MH}$ [editors]. Tobacco in Australia: Facts and issues. Melbourne: Cancer Council Victoria; 2020.

3. U.S. Department of Health and Human Services. The Health Consequences of Smoking - 50 Years of Progress: A Report of the Surgeon General. Atlanta: U.S. Department of Health and Human Services, Centers for Disease Control and Prevention, National Center for Chronic Disease Prevention and Health Promotion, Office on Smoking and Health, 2014.

4. Homa DM, Neff LJ, King BA, et al. Vital signs: disparities in nonsmokers' exposure to secondhand smoke--United States, 1999-2012. MMWR. 2015;64 (4): 103-8.

5. Zhang R, Chen L, Cao L, et al. Effects of smoking on the lower respiratory tract microbiome in mice. Respir Res 2019, 253 (2018).

6. Zhang R, Chen L, Cao L, et al. Effects of smoking on the lower respiratory tract microbiome in mice. Respir Res. 2018; 19(1): 253.

7. WHO report on the global tobacco epidemic, 2017 - executive summary: Monitoring tobacco use and prevention policies (Accessed on February 08, 2020).

8. Miyahara R, Takahashi K, Anh NT, et al. Exposure to parental tobacco smoking increased child hospitalization for lower respiratory infections but not for other diseases in Vietnam. Sci Rep. 2017; 7: 45481 snym okresie życia, są bardziej narażone na rozwój chorób przewlekłych, takich jak astma $(19,20)$.

Strategie zapobiegające paleniu skierowane do rodziców oraz propagowanie szczepień ochronnych mogą odegrać pewną rolę w zmniejszeniu zachorowalności wynikającej z narażenia dzieci na dym tytoniowy $(7,21)$. Należy poszukiwać nowych form interakcji z pacjentami, pamiętając, że edukacja ma zasadnicze znaczenie.

\section{WNIOSKI}

Dzieci z grypą oraz innymi infekcjami układu oddechowego są częściej narażone na bierne palenie. Ekspozycja na dym tytoniowy może prowadzić do zwiększenia ryzyka rozwoju zakażeń układu oddechowego, w tym grypy.

9. Bielska D, Kurpas D, Nitsch-Osuch A, et al. Exposure to environmental tobacco smoke and respiratory tract infections in pre-school children - a cross-sectional study in Poland. Ann Agric Environ Med. 2015; 22(3): 524-529.

10. Zhuge Y, Qian H, Zheng X, et al. Effects of parental smoking and indoor tobacco smoke exposure on respiratory outcomes in children. Sci Rep 10, 4311 (2020).

11. Han L, Ran J, Mak YW, et al. Smoking and Influenza-associated Morbidity and Mortality: A Systematic Review and Meta-analysis. Epidemiology. 2019; 30(3): 405-417.

12. Oberg M, Jaakkola MS, Woodward A, et al. A Worldwide burden of disease from exposure to second-hand smoke: a retrospective analysis of data from 192 countries. Lancet. 2011; 377(9760): 139-46.

13. Zgliczyński WS. Palenie tytoniu w Polsce. Infos BAS. 2017; 14(237); 1-4.

14. Salez N, de Lamballerie $X$, Zandotti C, et al. Improved Sensitivity of the Novel Xpert Flu Test for Detection of Influenza B Virus. J Clin Microbiol. 2013; 51(12): 4277-4278.

15. World Health Organization. WHO information for molecular diagnosis of influenza virus-update. WHO. 2015; 1-60.

16. 16. PZH-NIZP. Zakład Epidemiologii Chorób Zakaźnych i Nadzoru. Pracownia Monitorowania i Analizy Sytuacji Epidemiologicznej. Zachorowania i podejrzenia zachorowań na grypę w Polsce. 2018.

17. Pinkas J, Kaleta D, Zgliczyński WS, et al. The Prevalence of Tobacco and E-Cigarette Use in Poland: A 2019 Nationwide Cross-Sectional Survey. Int. J. Environ. Res. Public Health 2019, 16(23), 4820. 
18. Blank P, Falup-Pecurariu O, Kassianos G. et al. Received: 15.07.2020

Szczepienia przeciw grypie: podstawowe fakty dla Accepted for publication: 10.10.2020 r.

lekarza pierwszego kontaktu w Europie. 2nd ed. Otrzymano: 15.07.2020 r.

Warszawa: Fundacja Nadzieja dla Zdrowia, 2016. Zaakceptowano do publikacji:10.10.2020 r.

19. Neuman $\AA$, Hohmann C, Orsini N, et al. Maternal smoking in pregnancy and asthma in preschool children: a pooled analysis of eight birth cohorts. Am J Respir Crit Care Med. 2012; 186(10): 103743.

\section{Adres do korespondencji: \\ Address for correspondence: \\ Dr n. med. Andrzej Załęski}

Klinika Chorób Zakaźnych, Chorób Tropikalnych

20. Vandenplas O, Wiszniewska M, Raulf M, et al. EAACI position paper: irritant-induced asthma. Allergy. 2014;69(9): 1141-53.

i Hepatologii,

Warszawski Uniwersytet Medyczny, ul. Wolska 37, 01-201 Warszawa

21. Sureda X, Fernández E, López MJ, et al. telefon: 048600982185

Secondhand tobacco smoke exposure in open and semi-open settings: a systematic review. Environ e-mail: andrzejzaleski84@wp.pl Health Perspect. 2013; 121(7): 766-77. 